\title{
PEMIKIRAN HUKUM ISLAM KLASIK DAN MODERN: KARAKTERISTIK, METODE, PENGEMBANGAN, DAN KEBERLAKUANNYA
}

\author{
Didi Kusnadi \\ Pengadilan Tinggi Agama Bandung Jawa Barat \\ E-Mail: didi.kusnadi@yahoo.com
}

\begin{abstract}
Syekh Mahmûd Syaltût stated that Islamic law is a universal legal system that made it lives and thrives in society. Islamic law is an independent legal system, not taken from other laws, so it has own character. The sources of Islamic law are derived from the Koran, Sunna, and ijtihâd. The truth of ijtihâd is relative and dzanni, but it will be received by us if it is not contradicted to the Sharia or sacred texts. Thus, It makes a difference opinion among the scholars in the process of ijtihâd on how to formulate Islamic law (istinbâth al-ahkâm) which is caused by three things: First, the formulation of rules (al-tahsîs). There are scholars who hold to the understanding uslub or dalil syara' and some scholars adhered to the issues of branches (furu'); Second, the methodology (manhaj) or the formulation of the legal methods that used, both inductive and deductive; Third, aspects of thinking which is the fundamental basis of the scholars that used in ijtihâd. Development and validity of ijtihâd will always still be opened and dynamic, which is following the development of human thought and the dynamics of Islamic law.
\end{abstract}

\begin{abstract}
Abstrak
Syekh Mahmûd Syaltût telah menegaskan bahwa hukum Islam merupakan salah sistem hukum universal, yang mana menjadikan hukum Islam tersebut hidup dan berkembang dalam masyarakat. Hukum Islam merupakan sistem hukum yang berdiri sendiri dan tidak diambil dari hukum lain, sehingga melahirkan karakter tersendiri. Sumber hukum Islam yaitu: pertama, Al-Quran; Kedua, Sunnah; dan ketiga, adalah ljtihâd. Kebenaran ijtihâd bersifat relatif dan dzannî, terkecuali apabila kebenarannya tidak keluar dari syarî‘at dan nash. Hal ini menimbulkan perbedaan pada proses ijtihâd dalam menetapkan hukum (istinbâth al-ahkâm) yang disebabkan karena tiga hal: Pertama, formulasi kaidah (al-tahsîs) yaitu ada yang berpegang kepada pemahaman uslub/dalil syar'i dan ada pula yang berpegang kepada maslah-masalah cabang (furu'); Kedua, metodologi (manhaj) yaitu rumusan metode hukum dilakukan secara induktif dan secara deduktif; Ketiga, aspek pemikiran yang merupakan pijakan mendasar yang dipakai para ulama dalam berijtihâd. Pengembangan dan keberlakuan ijtihâd akan selalu terbuka dan tetap dinamis mengikuti perkembangan pemikiran manusia dan dinamika hukum Islam.
\end{abstract}

Kata Kunci:

Hukum Islam, Klasik, Modern

\section{A. Pendahuluan}

Di kalangan ahli hukum, syari'ah disebutkan lebih banyak memuat hukum-hukum yang bersifat teoritis dan masih memerlukan penafsiran untuk praktisnya. Hal ini disebabkan syari'ah lebih kepada prinsip-prinsip dasar hukum Islam itu sendiri. Sedangkan, fiqh justru lebih bersifat praktis dan menyentuh segi-segi hukum yang konkret dan horizontal, karena figh lahir dari produk pemikiran manusia, maka figh relatif mengandung interpretable dan dapat berubah sesuai dengan tuntutan realitas. Terlebih lagi dalam wacana hukum Islam modern, hukum diakui tat- 
kala hukum tidak semata-mata merupakan peraturan, tetapi harus termuat dalam suatu bingkai ketentuan hukum yang tertulis melalui proses taqnîn.

Perkembangan hukum Islam disinyalir oleh Joseph Schacht telah mengalami perubahan substansial pada segi-segi hukumnya disebabkan oleh: Pertama, pada awal waktu pengenalan teori hukum, mengindikasikan bahwa sumber hukum material hukum Islam bukan hanya Al-Quran dan Sunnah, tetapi juga ijtihâd (ra'yu); Kedua, pada masa modern hukum diakui apabila ditransformasikan ke dalam bentuk perundang-undangan (taqnîn) secara tertulis, legal dan formal sejalan dengan kebijakan politik hukum suatu negara. Karena dua hal itu, maka hukum Islam berlalu dipengaruhi oleh faktor sosial, budaya, politik, geografis dan pemikiran para ahli hukum. ${ }^{1}$

Oleh karena itu, berlakunya hukum Islam dalam kehidupan masyarakat muslim akan berhadapan dengan pemikiran masyarakat modern barat. Dimana perkembangan teknologi dan kebudayaan barat tanpa disadari telah berbaur dengan kaidah-kaidah dasar hukum Islam, sehingga keadaan ini secara simultan akan merangsang perubahan cara pandang dan pola pikir umat Islam dalam menjalankan hukum Islam. ${ }^{2}$ Tulisan ini menjelaskan karakteristik hukum Islam, metode, pengembangan dan keberlakuannya.

\section{B. Karakteristik Hukum Islam}

Dalam sebuah seminar hukum di Den Haag tahun 1937 M, Syekh Mahmûd Syaltût (Rektor Universitas Al-Azhar) dan Dr. Hasan Sûfi Abû Thâlib menegaskan bahwa: Pertama, hukum Islam merupakan salah satu sumber hukum umum; Kedua, hukum Islam merupakan hukum yang hidup dan berkembang dalam masyarakat; Ketiga, hukum Islam

${ }^{1}$ Joseph Schacht, Introduction of Islamic Law, terj. M. Said, dkk. (Jakarta: PPS \& PTAI \& Ditjen Binbaga Islam Depag RI. 1985), hlm.1. A.A. Fyzee, Out Lines of Muhammad Law (London: Oxford University Press. 1995), hlm. 15.

${ }^{2}$ Harun Nasution, Dasar Pembaharuan Hukum Islam dalam M. Yunan Yusuf et. Al. (ed), Cita dan Citra Muhammadiyah (Jakarta: Pustaka Panjimas. 1985), hlm. 13-14. merupakan hukum yang berdiri sendiri dan tidak diambil dari hukum lain. ${ }^{3}$

Berkenaan dengan hal itu, perkembangan hukum Islam yang berlaku dalam komunitas muslim di berbagai negara sangat dipengaruhi oleh identitas hukum Islam itu sendiri, ${ }^{4}$ antara lain:

\section{Sempurna (Paripurna)}

Syarî‘at Islam diturunkan dalam bentuk yang umum. Hukum awalnya bersifat tetap sedangkan substansinya berubah mengikuti 'illatnya. Hukum-hukum yang lebih rinci ditetapkan dalam kaidah dan pedoman umum, sedangkan penjelasan atau implementasinya diserahkan kepada ahli hukum yang memahami hakikat hukum. ${ }^{5}$

Pedoman-pedoman atau prinsip-prinsip dasar yang berlaku umum dalam syarî́at Islam mengindikasikan identitas hukum yang menunjukkan sifat kesempurnaannya, universal dan teknis, serta dapat diterima oleh masyarakat di semua tempat dan waktu. Kesempurnaan hukum Islam dengan sendirinya menempatkan diri sebagai hukum yang tertinggi dan seharusnya dapat diterapkan oleh komunitas muslim maupun non muslim, karena hukum ini melindungi hak-hak hukum setiap subyek.

\section{Elastis (Fleksibel)}

Selain bersifat sempurna, hukum Islam pun memiliki fleksbilitas dalam hal aplikasinya. Oleh karena itu, cakupan hukum Islam meliputi seluruh aspek kehidupan manusia yang sifatnya vertikal maupun horizontal. Dalam hukum Islam, tidak saja diatur hubungan antara manusia dengan Tuhannya (vertikal), tetapi juga hubungan manusia dengan manu-

${ }^{3}$ A. Hanafi, Pengantar dan Sejarah Hukum Islam (Jakarta: Bulan Buntang. 1970), hlm. 202-203. Menurut A. Hânafi, hukum Islam telah berlaku umum dan dapat menyesuaikan diri dengan kebutuhan hidup modern, sebagaimana ia telah mensinyalir dari Seminar Hukum di Den Haag-Belanda Agustur 1948 dan Paris-Perancis Juli 1951.

${ }^{4}$ Fathurrahman Djamil, Filsafat Hukum Islam (Jakarta: Logos Wacana Ilmu. 1997), hlm. 46.

${ }^{5}$ Anwar Haryono, Hukum Islam: Keluasan dan Keadilannya (Jakarta: Bulan Bintang. 1985), hlm. 113. Hasbie Ash-Shiddiqie, Pengantar Hukum Islam (Jakarta: Bulan Bintang. 1975), hlm. 23-24. dan Cik Hasan Bisri, hlm. 112. 
sia lainnya (horizontal), serta dengan lingkungannya.

Adapun munculnya perbedaan corak pemahaman hukum Islam dalam konteks fiqh banyak disebabkan oleh perbedaan pola pikir ahli hukum (mujtahid) dalam wacana pemikiran dan penelitian atas obyek-obyek hukum Islam (ijtihâd). ${ }^{6}$ Implikasinya jelas berpengaruh pada perbedaan corak madzhab hukum yang berlaku dalam masyarakat muslim. Hal ini manjadi bukti bahwa hukum Islam berlalu menyesuaikan diri dengan situasi, kondisi, waktu dan tempat. ${ }^{7}$

\section{Universal dan Dinamis}

Hukum Islam bersifat universal dan dinamis mengandung pengertian bahwa hukum Islam yang dimasukan dalam term fiqh mencakup bagian-bagian atas keseluruhan hukum dalam term syari'ah, sebagaimana telah disinggung sebelumnya, identitas hukum Islam yang mengandung dimensi vertikal dan horizontal dalam semua cakupan hukumnya telah menjadi ciri universalitas hukum Islam itu sendiri.

Adapun dinamika hukum Islam dapat diketahui dari proses perkembangan berlakunya hukum Islam sejak periode Rasul hingga periode modern dengan segala dimensinya. Perkembangan hukum Islam secara sistematis telah bergeser dari sistem hukum material yang umum dalam nash, kemudian direduksi dalam bentuk transformasi pemikiran hukum (ijtihâd) dan diimplementasikan menjadi berbagai bentuk pemikiran produk hukum (figh) hingga selanjutnya dikodifikasikan menjadi Qanûn.

\section{Sistematis}

Arti dari pernyataan bahwa hukum Islam bersifat sistematis adalah hukum Islam itu mencerminkan sejumlah doktrin hukum yang bertalian satu sama lain secala logis dan konkret. Hukum ini mencakup seluruh komponen hukum berupa pokok-pokok ajaran tentang etika, moral dan keadilan serta keyakinan terhadap Tuhan Yang Maha Pencipta.

\footnotetext{
${ }^{6}$ Ibid. hlm. 112

${ }^{7}$ Hasbie Ash-Shiddiqie, Dinamika dan Elastisitas Hukum Islam (Jakarta: Tintamas. 1975), hlm. 27.
}

Semua komponen hukum itu kemudia terintegrasikan ke dalam term umum yang disebut syarî́at ${ }^{8}$

Sedangkan perwujudan dari sistematisnya hukum Islam adalah Fiqh. Fiqh sebagai produk pemikiran orang Islam terhadap ajaran Islam sebagaimana digambarkan oleh para ahli hukum mencakup atas segi-segi secara khusus, seperti: 'ibâdah, mu'âmalah, jinâyah, siyâsah dan sebagainnya. Semua jenis pembidangan hukum Islam dalam bidang hukum Islam (figh) adalah suatu refleksi dari bentuk ketaatan orang Islam kepada ajaran Islam secara totaliter. ${ }^{9}$

Sistematika hukum Islam dapat berarti pula saling berhubungannya atau interaksi setiap bentuk dan unsur-unsur hukum secara sinergis dan organis. Karena hukum Islam berlaku secara fleksibel dan rigid, maka ia menyesuaikan diri dengan perkembangan dan kebutuhan hidup manusia baik secara individual maupun kolektif. Sehingga secara metodologis akan terbentuk suatu sistem hukum secara piramidal (hierarki hukum Islam).

\section{Ta'aqquli dan Ta'abbudi}

Ta'aqquli dan Ta'abbudi dalam karakteristik hukum Islam adalah hukum Islam mengandung muatan dimensi vertikal dan horizontal. Hukum Islam bersumber kepada wahyu yang mengandung muatan teologis menunjukan aturan tentang hubungan antara manusia dengan Tuhan yang diyakini sebagai pembuat hukum secara mutlak. Konsekuensinya ada keharusan bagi orang Islam untuk tunduk dan patuh terhadap hukum Islam.

Namun demikian, tidak semua hukum Islam itu kaidah norma hukumnya berbentuk khusus dan jelas, malainkan diperlukan suatu bentuk penafsiran atas segi-segi hukum yang umum. Pada tingkatan metodologi, interpretasi atas segi norma hukum dalam nash kemudian dikonkretkan menjadi produk hukum

\footnotetext{
${ }^{8}$ Ibn Qayyim al-Jawziyyah, I'lâm al-Muwaqqîn 'anRabbi al-'Âlamîn (Beirut: Dâr al-Fikr. t.th.), jilid III, hlm. 14.

${ }^{9}$ Muhammad Muslehudin, Filsafat Hukum Islam dan Pemikiran Orientalis, terj. Yudian Wahyudi (Yogyakarta: Tiara Wacana. 1992), hlm. 277-278.
} 
(figh) yang lebih menyentuh sisi praktis pelaksanaan hukum Islam.

\section{Sumber dan Metode Hukum Islam}

Pada kenyataan dewasa ini, hukum Islam terbagi ke dalam berbagai obyek-obyek materi hukum. Sebagian merupakan hukum tertulis (dikodifikasikan menjadi undang-undang), dan sebagian lagi merupakan hukum yang tidak tertulis, tetapi keberadaannya telah dipatuhi dan berlaku di masyarakat. Keadaan ini dapat diasumsikan merupakan keistimewaan dari hukum Islam itu sendiri, karena pada sisi tertentu hukum Islam berdasar kepada nash tapi pada sisi lain hukum Islam juga membuka diri terhadap faktor di luar nash (ijtihâd).

Berkenaan dengan hal tersebut, tidak dapat disanggah bahwa perumusan norma hukum Islam menjadi sebuah sistem hukum modern, hingga umat muslim mengenalnya sebagai sistem hukum yang harus ditaati dan dipatuhi dipengaruhi oleh beberapa hal: Pertama, kehadiran para ulama madzhab yang memiliki persepsi yang berbeda mengenai rumusan norma dan sistem hukum Islam; ${ }^{10}$ Kedua, hukum Islam dalam perkembangannya telah bergeser dari sudut normativitas syari'ah yang bersifat umum menjadi fiqh sebagai hukum substantif;" Ketiga, perbedaan menggunakan metode hukum Islam melahirkan produk hukum yang berbeda pula; ${ }^{12}$ dan Keempat, masuknya anasir-anasir hukum ke dalam wilayah pengkajian hukum Islam, menyebabkan hukum Islam berlaku fleksibel dan rigid. ${ }^{13}$

Pengembangan pemikiran hukum Islam selain berangkat dari pengertian dasar hukum Islam, juga bersinergi dengan penyelesaian masalah seputar sumber dan metode hukum Islam. Sebagaimana disinggung oleh

\footnotetext{
${ }^{10}$ Joseph Schact, An Introduction of Islamic. hlm. 3-4.

${ }^{11}$ Hasbie Ash-Shiddiqie, Dinamika dan Elastisitas. hlm. 27.

${ }^{12}$ Yûsuf Musâ, Târîkh al-Fiqh al-Islâmiy (Kairo: Mesir. t.th), hlm. 10. Manna' al-Qathân, al-Tarîkh wa al-Fiqh fîal-Islâm (t.t.: Mu'assasah al-Risâlah, t.th.), hlm. 14 .

${ }^{13}$ Amir Syarifudin, Pengertian dan Sumber Hukum Islam dalam Falsafah Hukum Islam (Jakarta: Bumi Aksara-Depag RI. 1992), hlm. 15.
}

para ahli fiqh, bahwa sumber hukum Islam ada tiga, yaitu: Al-Quran, Sunnah dan ijtihâd. Adapun metode hukum Islam adalah rumusan-rumusan teoritik untuk menyelesaikan berbagai permasalahan hukum Islam dalam wilayah ijtihâd, seperti ljma', Qiyash, Istihsân, Istishab, Mashlahah Mursalah, Syadz al-Dzarî'ah, 'Urf dan sebagainya. ${ }^{14}$

\section{Sumber Hukum Islam}

a. Al-Quran sebagai Sumber Hukum Islam Al-Quran merupakan sumber utama dan sumber pokok hukum Islam. Bagi orang Islam tidak diperkenankan mengambil dasar hukum dan jawaban atas proble-matikanya dari luar Al-Quran selama hukum dan jawaban tersebut dapat ditemukan dalam nashnash Al-Quran. Apabila ditilik dari segi hierarki hukum Islam, maka produk hukum dan undang-undang buatan manusia tidak boleh menyalahi kaidah-kaidah dan norma-norma hukum dalam Al-Quran. Kesesuaian dan kesejiwaan hukum dengan Al-Quran adalah sesuatu yang dikehendaki, sehingga manusia mencapai kesejahteraannya. Dengan kata lain, Al-Quran bukan sekadar dipahami sebagai kalam Allah, tetapi merupakan pedoman tertinggi (way of life) bagi penentu arah kehidupan manusia. ${ }^{15}$

Bukti yang menyatakan bahwa Al-Quran merupakan sumber dan dalil hukum yang utama dan pokok dapat ditemukan dalam ayat-ayat Al-Quran sendiri. Lebih dari tiga puluh kali Al-Quran menyuruh umat Islam untuk mematuhi Allah yang berarti mematuhi semua ucapan-ucapan-Nya. Semua ucapan Allah dalam Al-Quran disebut sebagai hukum karena mengandung muatan materi-materi hukum tertentu. Kasus Muadz bin Jabâl ketika diutus Rasulullah ke Yaman adalah bukti real tatkala Al-Quran dijadikan sebagai pato-

\footnotetext{
${ }^{14}$ Fathurrahman Djamil, Filsafat Hukum. hlm. 7-12. la menjelaskan secara gamblang tentang pengertian serta hubungan antara Syari'ah, Fiqh dan Hukum Islam. Bandingkan dengan Dede Rosyada, Hukum Islam dan Pranata Sosial (Jakarta: Rajawali Press. 1994), hlm. 1-4; Lihat pula Hasbie Ash-Shiddiqie, Falsafah Hukum Islam (Jakarta: Bulan Bintang. 1993), hlm. 31-42.

${ }^{15}$ Abdul Wahab Khallaf, Ilmu Ushûl al-Fiqh (Kairo: Maktabah Tijâriyah al-Kubrâ. 1969), hlm. 22. Muhammad Abû Zahrah, Ushûl al-Fiqh (Mesir: Dâr al-Fikr al'Arabiy. 1973), hlm. 76.
} 
kan dasar norma hukum utama dalam sistem hukum Islam.

Seluruh ayat Al-Quran dari segi lafazh dan maknanya adalah qath'iyy al-wurûd dan makna Al-Quran datang dari Allah tanpa diragukan lagi keasliannya (muthawâtir). Sedangkan dari segi dalalah hukumnya ayat AlQuran, sebagian bersifat qath'iyy al-dalâlah dan sebagian lainnya dzanniyy al-dalâlah. Ayat-ayat yang qath'iyy al-dalâlah sudah dianggap jelas dan tidak membutuhkan penafsiran, sedang ayat-ayat yang dzanniyy al-dalâlah masih samar, karenanya memerlukan penafsiran manusia. Berbagai jalan untuk meneliti penunjukkan hukum dalam Al-Quran tampak pada bentuk ayat-ayat yang sudah tegas hukumnya (muhkam) dan samar hukumnya (mutasyâbih). Hal ini terjadi karena: Pertama, ada beberapa ayat Al-Quran yang memiliki dua makna (musytarak) seperti lafazh "qurû" yang diartikan dengan suci dan haid dalam QS 2: 228. Kedua, ada ayat-ayat Al-Quran yang menggunakan bentuk ibarat atau kiasan seperti lafazh "yadd" yang berarti tangan atau kekuasaan dalam QS 48:10.

Berkenaan dengan penjelasan mengenai hukum-hukum dalam Al-Quran mencakup tiga sifat, yakni: Pertama, hukum-hukum AlQuran dianggap telah sempurna apabila telah terperinci urutan maupun maksudnya dan tidak perlu ada penafsiran lagi. Seperti hukum waris dalam QS 4:11-12; Kedua, hukum-hukum dalam Al-Quran mengambil mudel yang bersifat umum (global term), sehingga memerlukan penjelasan atas ayatayat hukum yang berbentuk 'amm dengan ayat berbentuk khas, atau yang mujmal oleh yang mubayyan, sehingga ayat Al-Quran dengan sendirinya bersifat fleksibel dan rigid; dan Ketiga, hukum-hukum Al-Quran dengan ibarat atau isyarat dimaksudkan penunjukkannya secara tersurat (tekstual) maupun tersirat (kontekstual). ${ }^{17}$

Kemudian dari sekian banyak rumusanrumusan norma hukum dalam Al-Quran, secara umum dikelompokkan menjadi tiga, yaitu:

1) Hukum akidah (I'tiqâdiyyah) yaitu hukum-hukum yang menyangkut hubung84.

\footnotetext{
${ }^{16}$ Fathurrahman Djamil, Filsafat Hukum. hlm. 82-
}

${ }^{17}$ Ibid. hlm. 85-86. an manusia dengan Allah dalam masalah keimanan dan ketaqwaan.

2) Hukum akhlaq (Khulûqiyyah) yaitu hukum-hukum yang menyangkut hubungan manusia dengan manusia serta makhluk lainnya dalam kerangka beragama, bermasyarakat dan bernegara.

3) Hukum syari'ah (Syar'iyyah) yaitu kekhususan hukum-hukum yang berhubungan antara manusia dengan Allah dan erat kaitannya dengan hubungan sesama manusia yang diwujudkan dalam refleksi hukum-hukum tentang masalah ibadah dan mu'âmalah dalam arti sempit maupun luas. ${ }^{18}$

b. Sunnah sebagai Sumber Hukum Islam Sebagaimana telah dijelaskan, bahwa AlQuran ditinjau dari segi wurûd dan tsubûtnya adalah qath'iy. Sedangkan Sunnah, selain yang mutawatir, ada juga yang dzanniyy alwurûd. Dari kenyataan inilah, jumhur ulama menyatakan bahwa Sunnah menempati urutan kedua sumber hukum Islam setelah AlQuran. Dalam kaitan ini, al-Syâthibi dan alQasimi memberi pembahasan khusus dalam kitab al-Muwâfaqât fî Ushûl al-Ahkâm dan kitab al-Mahâsin al-Ta'wîl. ${ }^{19}$

Argumentasi keduanya perihal kedudukan Sunnah sebagai hukum Islam yang kedua dijelaskan dengan argumentasi rasional dan argumentasi tekstual. Di antara argumentasi itu adalah :

1) Bahwa Al-Quran bersifat qath'iyy al-wurûd, sedangkan Sunnah bersifat dzanniyy al-wurûd. Atas dasar itu, maka yang qath'iy harus didahulukan dari pada yang dzanniy.

2) Bahwa Sunnah dapat berfungsi sebagai penjabar (bayân) bagi Al-Quran. Keberadaan Sunnah tergantung kepada keperluan bayan bagi Al-Quran, karenanya Sunnah selalu beriringan dengan AlQuran.

3) Bahwa ada beberapa keterangan hadits yang menjelaskan urutan sumber hukum Islam kedua setelah Al-Quran adalah Sunnah dan ketiga adalah ijtihâd. Hal ini sebagaimana hadits tentang Muadz bin Jabâl ketika ditanya oleh Rasulullah

\footnotetext{
${ }^{18}$ Ibid. hlm. 87-90.

${ }^{19}$ lbid. hlm. 91. ; A. Djazuli, Ushûl Figh. hlm. 60.
} 
SAW tentang proses menyelesaikan perkara-perkara dan hukum.

Berbeda dengan pendapat di atas, sekelompok ulama lain justru berpendapat sebaliknya, di mana Sunnah diposisikan sebagai penentu terhadap Al-Quran. Artinya, Sunnah ditempatkan di urutan pertama, baru kemudian Al-Quran, dengan alasan: Pertama, bahwa Al-Quran yang bersifat mujmal memerlukan penjelasan Sunnah, sehingga tampak lebih dominan daripada Al-Quran. Kedua, ada beberapa ayat Al-Quran yang memiliki makna ganda, dan Sunnah memberikan alternatif sebagai pilihan. ${ }^{20}$

Kendatipun terjadi tarik menarik secara metodologis antara keduanya, tetapi antara Al-Quran dan Sunnah memiliki posisi dan eksistensi yang berbeda. Terkecuali jika dilihat dari segi pemahaman nash, maka dapat saja keduanya sisejajarkan. Yang jelas keduanya tidak dapat dipisahkan sebagai sumber pokok hukum Islam. Sebagaimana dilihat dari segi fungsi Sunnah terhadap Al-Quran antara lain: Pertama, sebagai dalil yang memperkuat (tawkîd) bagi Al-Quran dan tidak menjelaskan apalagi menambah ketetapan Al-Quran; Kedua, Sunnah berfungsi memperjelas atau merinci apa yang telah digariskan dalam AlQuran; Ketiga, Sunnah berfungsi untuk menetapkan hukum-hukum yang belum diatur secara tegas dalam Al-Quran. ${ }^{21}$

Apabila dilihat dari bentuk-bentuk Sunnah Rasul, yakni berupa perkataan (qawliy), perbuatan (filliy) dan ketetapan (taqrîriy), maka semuanya dapat direduksi pada tingkatan norma hukum. Hal ini dilandasi oleh suatu pemikiran bahwa Al-Quran bersifat global, keberadaan Sunnah dapat mengkhususkan unsur-unsur kepentingan hukum dalam Al-Quran yang bersifat dharûriyyât, hâjiiyyât dan tahsîniyyât dengan memperhatikan tujuan kemaslahatan hukum yang bersifat

${ }^{20} \mathrm{lbid}$. hlm. 92-93. Sebagaimana uraian lengkapnya dalam Abu Ishaq al-Syâthibi, al-Muwâfaqât fî Ushûl al-Ahkâm (Beirut: Dâr al-Fikr, t.th.), Jilid I, hlm. 3-5.

${ }^{21}$ Ibid. hlm. 94-94. A. Djazuli, Ushûl Figh. hlm. 6466. Bandingkan dengan penjelasan Abdul Wahhâb Khallaf, Al-Siyâsah al-Syar'iyyah (Kairo: Dâr al-Anshâr. 1977), hlm. 41-43. umum. Hal ini akan lebih tampak bersinggungan dalam mekanisme ijtihâd.

\section{c. Ijtihâd sebagai Sumber Hukum Islam}

Secara harfiyah, ijtihâd berasal dari kata “juhd' yang berarti sungguh-sungguh dalam melaksanakan suatu perbuatan. Istilah ini pada mulanya digunakan dalam bidang jurisprudensi (figh) untuk menyatakan salah satu kaidah yang ditetapkan oleh para ulama madzhab dan menyusul pembentukkannya. Apabila suatu kasus tidak ditemukan penjelasannya dalam Al-Quran dan Sunnah, maka ia harus berijtihâd dengan ra'yunya.

ljtihâd dapat dikatakan sebagai rekonstruksi pemikiran seorang fakih di dalam menyelesaikan kasus-kasus hukum baru yang dilakukan melalui penalaran akal secara mendalam disertai bukti-bukti dan hujjah yang kuat dengan tetap berpegang kepada sumber yang pokok yakni Al-Quran dan Sunnah. Karena ia merupakan rekonstruksi pemikiran akal, maka terdapat dua kecenderungan produk ijtihâd, yaitu bisa jadi hasil ijtihâd seseorang itu benar, tapi bisa juga salah atau keliru. ${ }^{22}$

Tampaknya hampir semua ulama madzhab sepakat bahwa kebenaran ijtihâd bersifat relatif dan zanni, terkecuali apabila kebenarannya tidak keluar dari kemauan syarî́at di dalam nash. Hal ini menimbulkan asumsi bahwa munculnya perbedaan pendapat di dalam proses ijtihâd untuk menetapkan hukum (istinbâth al-ahkâm) adalah karena tiga hal: Pertama, formulasi kaidah (altahsîs) yaitu ada yang berpegang kepada pemahaman uslub/dalil syara' dan ada pula yang berpegang kepada maslah-masalah cabang (furu'); Kedua, metodologi (manhaj) yaitu rumusan metode hukum dilakukan secara induktif dan secara deduktif. Hal ini akan berimplikasi pada adanya dua corak kaidah, yakni kaidah Ushûl dan kaidah fiqh; Ketiga, aspek pemikiran yang merupakan pijakan mendasar yang dipakai para ulama dalam berijtihâd. Ada yang lebih dominan berpegang kepada nash/teks dan ada yang berpegang kepada ra'yu/konteks. ${ }^{23}$

\footnotetext{
${ }^{22}$ Ibid. hlm. 96-103.

${ }^{23}$ Murtadha Muthahari dan M. Baqir Ash-Shadr, Pengantar Ushûl Fiqh dan Ushûl Fiqh Perbandingan, terj.
} 
Sebagai implikasi dari tiga hal di atas, maka dalam kajian pemikiran hukum Islam dikenal dua aliran utama dalam madzhab hukum Islam, yaitu aliran fuqaha yang berpegang pada nash atau biasa disebut dengan ahl al-hadîts/mutakallimîn (Imam Syâfi'i dan pengikutnya) dan aliran fuqaha yang lebih berpegang kepada ra'yu/akal dalam merumuskan metode hukumnya, dikenal sebagai ahl al-ra'yu (Imam Hânafi dan pengikutnya).

Di antara hal-hal yang diperselisihkan oleh para ulama dan dua aliran besar dalam hukum Islam tentang kedudukan sumbersumber hukum Islam adalah: Pertama, masalah hadits/sunnah yang diperdebatkan sisi orisinalitas dan validitasnya baik dari segi sanad, rawi maupun materi (matan) haditsnya serta tingkat orientasi dan kecenderungan ulama di dalam memakai hadits sebagai dasar hukum; Kedua, perbedaan pendapat tentang sumber hukum Islam selain Al-Quran dan Sunnah, yaitu Qiyash, Istiḩsân, Mashlahah al-Mursalah, dan sebagainya. ${ }^{24}$

\section{Metode Hukum Islam}

Di samping itu, pemahaman terhadap dalil-dalil nash cenderung beragam dan sangat tergantung kepada cara pandang dan penggunaan metodologi hukum yang dipakai. Seringkali pada sebagian ulama memahami dan menggali hukum Islam dengan pendekatan tekstual, tetapi sebagian yang lain menggunakan pendekatan kontekstual. Hal ini akan menimbulkan produk ijtihâd yang tentunya berbeda-beda baik dari segi rumusan metodologinya sampai pada ketetapan hukumnya, sebagaimana metode berikut: ${ }^{25}$

a. Metode Induktif

Metode induktif diperkenalkan oleh aliran mutakallimin (ahl al-hadîts) yang menetapkan kaidah hukum yang umum dan ditunjukkan oleh nash dan akal, tanpa terikat oleh hukum-hukum furu'. Ulama Syâfi'iyyah, Malikiyyah, Hambaliyyah, Syi’ah Imâmiyyah, Syi'-

\footnotetext{
Satrio Pinandih dan Ahsin Muhammad (Jakarta: Pustaka Hidayah. 1993), hlm. 44-50.

${ }^{24}$ Rachmat Syafe'i, Pengantar Ushûl Fiqh Perbandingan (Bandung: Piara. 1994), hlm. 44-47.

${ }^{25}$ Fathurrahman Djamil, Filsafat Hukum. hlm. 108.
}

ah Zaydiyyah dan Syi'ah Ibâdiyyah disebutsebut mengikuti langkah-langkah metodologi hukum induktif menurut Imam Syâfi'î. Hal ini diikuti pula oleh ulama kalam seperti kalangan Mu'tazilah dan 'Asy'ariyyah yang sarat dengan muatan teologi dan filsafat.

Diantara langkah-langkah metode hukum aliran mutakallimin adalah: ${ }^{26}$

1) Merumuskan kaidah-kaidah Ushûl dengan penyandaran kepada aspek kebahasaan (linguistik), sehingga metode aliran ini tampak kurang atau tidak menyentuh masalah-masalah furu'.

2) Prinsip-prinsip dasar logika mantik dan teori konklusi banyak dipakai oleh aliran ini.

3) Dalil-dalil hukum di dalam nash lebih banyak dipahami melalui pendekatan tekstual/semantik, dan relatif sedikit menggunakan pendekatan kontekstual/ tematik.

b. Metode Deduktif

Metode deduktif diperkenalkan oleh aliran rasionalis ( $a \mathrm{hl}$ al-ra'yu) yang menetapkan kaidah-kaidah hukum dengan penalaran akal dan senantiasa terikat oleh masalah-masalah furu'. Jika terdapat kaidah hukum yang bertentangan dengan hukum furu', maka mereka menyandarkan pendapatnya kepada imam-imam mereka. Imam Abû Hânafi dan murid-muridnya dianggap mewakili dari ulama aliran rasionalis ini.

Di antara langkah-langkah metode hukum aliran rasionalis adalah: ${ }^{27}$

1) Merumuskan kaidah-kaidah Ushûl disesuaikan dengan masalah-masalah furu', lebih menyentuh figh, aktual dan realistis.

2) Prinsip-prinsip dasar logika dan analogi rasional banyak dipakai oleh aliran ini.

3) Dalil-dalil hukum di dalam nash banyak dipahami dengan pendekatan kontekstual/ tematik, kecuali dalil-dalil tertentu yang memang sudah jelas makna hukumnya.

\footnotetext{
${ }^{26}$ Ibid. hlm. 109. Rachmat Syafe'i, Pengantar Ushûl. hlm. 31-43.

${ }^{27}$ Abdul Wahhâb Ibrâhim Abû Sulaymân, Fikr alUshûliy (Jeddah: Dâr al-Syurûq. 1983), hlm.447-448.
} 
c. Metode Campuran Induktif-Deduktif (Konvergensi)

Metode campuran ini dalam langkahlangkah perumusan metode hukumnya lebih banyak memadukan kedua aliran sebelumnya. Di dalam kasus tertentu aliran ini menggunakan metode induktif, tapi dalam kasus lain aliran ini juga menggunakan metode deduktif. Penggunaan dua metode sekaligus sangat tergantung kepada adanya illat hukum yang berimplikasi pada perubahan hukum yang disesuaikan dengan situasi dan kondisi. ${ }^{28}$

Sebagai contoh, banyak kasus-kasus yang ditampilkan dalam kitab Badî'u al-Nidzâm karangan Muzhaffaruddin al-Sa'ati dan kitab Jam‘u al-Jawâni karangan Tajuddîn alSubki al-Syâfiîi disesuaikan dengan memadukan metode hukum induktif dan deduktif serta pendektan tekstual dan kontekstual. Munculnya aliran campuran ini sesungguhnya merupakan antitesa dari kedua aliran sebelumnya yang saling tarik-menarik mengenai keunggulan dan kelemahan masing-masing di dalam merumuskan metode hukum yang sistematis. ${ }^{29}$

Kendatipun masing-masing aliran memiliki rumusan metodologi hukum yang berbeda-beda dan lebih menyentuh aspek-aspek substansial hukum Islam, tetapi target utama penelitian dan pengkajian hukum Islam adalah bagaimana seorang mujtahid mengistinbath hukum dari dalil-dalilnya. Selain itu, dalam mekanisme istinbath hukum seorang mujtahid perlu memperhatikan prinsip-prinsip dasar hukum Islam, sehingga tercapai tujuan syarî́at (maqâshid al-syarî́ah) secara keseluruhan. ${ }^{30}$

\footnotetext{
${ }^{28}$ lbid. hlm. 453-455. A. Djazuli, Ushûl Figh. hlm. 108-109.

${ }^{29}$ Rachmat Syafe'i, Pengantar Ushûl. hlm. 41-43.

${ }^{30} \mathrm{Ibid}$. Analisis Penulis tentang munculnya aliran yang berbeda dalam konteks ijtihad semisal aliran mutakallimin (ahl al-hadîts) dan aliran rasionalis (ahl al-ra'yi) tidak hanya terjadi di kalangan Sunni antara pengikut Imam Syâfi'î dan pengikut Imam Abû Hanifah, akan tetapi juga terjadi di kalangan Syi'ah. Pemikiran hukum Islam dalam kegiatan Ijtihad para ulama Syi'ah mengkristal menjadi dua corak, yakni ahl al-hadits yang dipelopori oleh sekte Syi'ah Imâmiyah, Zayidiyyah dan Ibâdiyyah, serta ahl al-ra'yi yang dipelopori oleh sekte Syi'ah Ja'fariyyah, Isma'iliyah dan Sabaiyah.
}

\section{Prinsip-prinsip Pengembangan Hukum Islam}

Disamping itu, ijtihâd tidak hanya dipahami secara sempit dalam arti rekonstruksi pemikiran di bidang hukum Islam, melainkan ijtihâd dipandang sebagai wacana untuk membangun suatu peradaban manusia, dan khususnya dalam pengem-bangan pengetahuan dan sains. Jadi, suatu pandangan yang keliru apabila dikatakan oleh sebagian orang bahwa 'pintu ijtihâd telah tertutup', padahal pola pikir dan cara pandang manusia senantiasa berubah dan dinamis. Atas dasar itu, maka pintu ijtihâd akan selalu terbuka dan tetap dinamis mengikuti perkembangan pemikiran manusia dan dinamika hukum Islam itu sendiri. ${ }^{31}$

Di antara penyebab kenapa hukum Islam dapat berlaku secara dinamis adalah karena terdapat-prinsip-prinsip dasar pengembangan hukum Islam Islam, antara lain:

\section{Meniadakan Kepicikan dan Tidak Memberatkan (عدم الحرج)}

Prinsip ini sangat jelas tampak dalam proses penetapan hukum Islam. Pada umumnya hukum-hukum itu disyarî́at kan menunjukkan bahwa hikmahnya adalah untuk memberi kemudahan dan keringanan. Karena tabiat manusia tidak menyukai beban yang membatasi kemerdekaannya dan manusia suka memperhatikan hukum dengan sangat hati-hati. Manusia dalam mentaati hukum terbatas oleh pilihan-pilihan di mana apabila sanggup melaksanakannya.

Atas dasar itu, hukum Islam diberlakukan sesuai dengan fitrah manusia dan bukan karena kehendak-kehendak Allah semata. Hal demikian ditujukan agar setiap manusia mengarahkan dirinya dengan penuh kesadaran menuju kepada toleransi, persamaan, kemerdekaan dan amar ma'ruf nahî al-munkar. Sebagai contoh, beberapa keterangan dalam

${ }^{31}$ Ibid. hlm. 3. Penulis mengambil pemahaman dari sifat dan karakteristik hukum Islam yang elastis dan dinamis. Bila saja perkembangan ijtihad diangggap pintunya telah tertutup pada periode taklid, hal demikian semata-mata disebabkan kebanyakan ulama atau fuqaha enggan untuk menemukan pemikiran baru dalam ijtihad, dan mereka (ulama taklid) lebih suka merekonstruksi ulang dan atau senantiasa menyandarkan ijtihadnya kepada guru-guru mereka. 
Al-Quran yang mengisyaratkan adanya keringanan (rukhshah) dalam obyek hukum tertentu yang dianggap memberatkan (dharûrah) yaitu QS 5:6, hingga lahirlah kaidah figh yang berbunyi "Keadaan terpaksa menjadikan apa yang semula terlarang menjadi boleh" (الضرورات تبيح المحظورات).

Dari uraian itu, maka dalam beberapa situasi keberlakuan hukum Islam tidak kaku (rigid), tetapi dapat menyesuaikan diri dengan situasi dan kondisi secara fleksibel. Oleh Karena itu, dalam kaidah fiqh dikenal suatu kaidah yang berbunyi: "Berubahnya suatu hukum dipengaruhi oleh situasi dan kondisi serta waktu dan tempatnya" (والامكنة والاحوال (تغير الاحكام بتغير الازمنة والازمان argumen teoretis apapun yang dapat membantah adanya dinamika atau perubahan keberlakuan hukum Islam.

\section{Menyedikitkan Beban ( تقليل النكليف )}

Prinsip menyedikitkan beban dalam hukum Islam tidak hanya ditujukan untuk memenuhi kebutuhan-kebutuhan dan peristiwaperistiwa yang mengharuskan adanya ketetapan hukum. Hukum-hukum yang ditentukan oleh Allah dan Rasul-Nya bukan sekedar untuk menjawab persoalan-persoalan hukum di masa itu, melainkan dijadikan pedoman untuk menjawab persoalan-persoalan baru di masa datang. Sehingga betapapun kemampuan manusia berbeda-beda dalam menerima berlakunya hukum Islam, semuanya didasarkan pada pertimbangan untuk meringankan beban hukum. ${ }^{33}$

Sehingga Allah SWT mensinyalir kepada manusia untuk tidak banyak bertanya tentang masalah hukum, jika memang manusia tidak mampu melaksanakannya sebagaimana diterangkan dalam QS 5:101, 2:185 dan 4:28. Bahkan Rasulullah SAW juga menerangkan hal serupa tentang larangan menyia-

${ }^{32}$ Ibnu Qayyîm al-Jawziyyah, I'lam al-Muwaqqîn (Beirut: Dâr al-Fikr. t.th.), jilid III, hlm. 14. Kaidah "Taghayyar al-ahkâm bi taghayyur al-Azminah wa al-Amkinah wa al-Ahwâl wa al-Azmân" diambil dari rumusan kaidah "Taghayyar al-Fatwâ bi Taghayyur al-Azminah wa al-Amkinah wa al-Sifat wa al-Hukm."

${ }^{33}$ Fathurrahman Djamil, Filsafat Hukum. hlm. 6869. Abdul Wahab Khallaf, Ilmu Ushûl. hlm. 23-24. nyiakan harta benda, karena yang telah halal jelas halalnya dan yang haram pun jelas haramnya. Dari pemikiran tersebut, kemudian lahir kaidah Ushûl yang menyebutkan: "Bahwa asal hukum segala sesuatu adalah boleh kecuali ada dalil yang mengharamkannya" ( الاصل فى الاشياء الاباحة حتى يقوم الدليل على التحريم). Berdasar kaidah tersebut, maka tidak ada alasan bahwa hukum Islam memberatkan, yang sudah tentu adalah elastisitas hukum Islam akan meringankan semua beban hukum. ${ }^{34}$

\section{Penetapan Hukum secara Bertahap (تدريجيا ( ت}

Penetapan hukum Islam secara bertahap merupakan prinsip utama yang pernah terjadi dan berlaku pada masa kenabian. Diyakini bahwa setiap penetapan hukum mempunyai latar belakang historis dan sebab-sebab tertentu hingga diberlakukannya sebagai hukum yang tetap dan mengikat. Hikmah dari penetapan hukum secara bertahap adalah untuk mempermudah mengetahui isi dan materi suatu hukum serta lebih memantapkan pemahaman terhadap putusan-putusan hukum sesuai keadaan situasi dan kondisi. ${ }^{35}$

Dalam sosiologi Ibnu Khaldun menyatakan bahwa dalam suatu masyarakat tradisional yang tingkat intelektualnya masih rendah, akan menentang apabila ada sesuatu yang baru atau sesuatu yang datang kemudian dalam kehidupannya, lebih-lebih apabila yang baru itu bertentangan dengan tradisi, maka masyarakat akan memberikan respon, yang kalau tidak menerima pasti menolaknya. Karenanya Al-Quran dalam QS 2:219, $4: 43$ dan $5: 90$ memberikan gambaran bagaimana perubahan hukum tentang haramnya khamr. Hal ini sejalan dengan kaidah fiqh yang berbunyi "Perubahan hukum itu sesuai tergantung kepada ada atau tidak adanya illat" (الحكم يدور مع علثه وجودا وعدما).36

\footnotetext{
${ }^{34}$ A. Djazuli, Ushûl Fiqh. hlm. 20-23.

${ }^{35}$ Ibid. hlm. 62-63.

${ }^{36}$ Ibid. hlm. 32. A. Hânafi, Pengantar dan Sejarah. hlm. 29.
} 


\section{Memperhatikan Kemaslahatan Manu- sia}

Sebagaimana telah disinggung sebelumnya bahwa Allah SWT banyak membuat ketetapan-ketetapan hukum yang disertai dengan sebab-sebab dan tujuan hukum itu. Banyak sekali ditemui di dalam dalil-dalil hukum yang ditujukan untuk kemaslahatan manusia. Dalil-dalil penetapan hukum itu tidak pernah meninggalkan kepentingan masyarakat sebagai pertimbangan hukum. Karena pola kehidupan terus berubah, maka dalam hal perubahan hukum dan atau penggantiannya senantiasa diarahkan untuk mencapai kemaslahatan umum. ${ }^{37}$

Allah pernah menyuruh umat Islam untuk shalat megarahkan kiblatnya ke Bayt alMaqdis selama 17 bulandalam QS 2:144. Selain itu, contoh lain berkenaan dengan masa tunggu (iddah) bagi wanita yang ditinggal mati suaminya selama 4 bulan 10 hari dalam QS 2:24. Semua keterangan itu ditujukan untuk kemaslahatan manusia dan sesuai dengan kaidah yang berbunyi: "Meniadakan kemadharatan harus didahulukan untuk memperoleh kemaslahatan" ( دفع المفاسد وجلب (البعالح ) (المصالح

Di samping itu, penentuan hukum senantiasa didasarkan kepada tiga sendi pokok, yaitu: Pertama, hukum-hukum itu ditetapkan untuk memenuhi kebutuhan akan hukum; Kedua, hukum-hukum itu ditetapkan oleh suatu kekuasaan yang berhak menetapkan hukum dan menundukkan masyarakat karena hukum itu; dan Ketiga, hukum-hukum itu ditetapkan sesuai dengan kadar kesanggupan manusia sehingga dapat memperoleh kemaslahatan sesuai dengan tujuan hukum Islam (maqâshid al-syarî́ah).

\section{Mewujudkan Keadilan yang Merata}

Dalam sudut pandang hukum Islam, prinsip keadilan sesungguhnya fondasi utama bagi upaya penegakan kepastian hukum (law enforcement). Semua orang bersamaan

\footnotetext{
${ }^{37}$ Ibid. hlm. 63-64. Fathurrahman Djamil, Filsafat Hukum. hlm. 71-73.

38 'Ijuddin bin Abd Salam, Qawâ'id al-Ahkâm fî alMashâlih al-Anâm. lihat pula Abdul Wahab Khallaf, Ilmu Ushûl. hlm. 26-27.
}

kedudukannya di depan hukum, dan syarî́at Islam memberikan sanksi yang tegas bagi setiap pelanggar hukum tanpa kecuali. Adalah isyarat Rasulullah SAW dalam sabdanya: "Bila saja putriku Fatimah mencuri, niscaya aku akan potong tangannya." (al-Hadits). Hal ini sejalan dengan QS 5:8 bahwa Allah SWT menghendaki ditegakkannya prinsip keadilan di dalam hukum.

Di antara kaidah-kaidah hukum yang harus diperhatikan dalam menerapkan hukum adalah: Pertama, mewujudkan keadilan bagi terpeliharanya hak-hak asasi manusia; Kedua, hukum dutujukan untuk kesejahteraan dan kemakmuran masyarakat; Ketiga, hukum diberlakukan sesuai dengan kesepadanan dan tingkat kemampuan melaksanakannya; Keempat, setiap pelanggar hukum hendaknya diberikan sanksi dengan cara adil dan bijaksana; Kelima, harus ada keyakinan bagi setiap pelanggar hukum sama saja melawan ketentuan Allah dan Rasul-Nya. ${ }^{39}$

Pada gilirannya, dari rumusan kaidahkaidah hukum tersebut penegakan hukum adalah yang paling utama, sebagaimana disinyalir dalam QS 4:58, 105 dan 153, 5:6. Penegakan hukum yang ditujukan untuk keadilan akan menjamin kemaslahatan bagi setiap individu. Hal ini hendaknya dilaksanakan dalam setiap tingkatan dan jenis hukum menurut ketentuan hukum Islam seperti kaidah fiqh yang berbumyi: "Apa yang tidak bisa dilaksanakan seluruhnya, jangan ditinggalkan seluruhnya." (ما لا يدرك كله لا يترك كله)

Kendatipun dalam hal pengembangan hukum Islam merupakan tugas manusia untuk merekonstruksinya dalam figh tetapi prinsip-prinsip hukum Islam itu harus sejalan dengan asas-asas pembinaan hukum Islam yang menjadi fondasi utama., antara lain: (1) Tawhid dan eksistensi manusia dalam QS 2:30, 24:55 dan 6:165; (2) Keadilan dalam QS 4:58, 5:6 dan 4:105; (3) Musyawarah dalam QS 3:159, 42:38 dan 4:49; (4) Persamaan dalam QS 4:1 dan 49:33; (5) Kebebasan dalam QS 5:32, 4:58 dan 17:33; (6) Amr Ma'ruf Nahi Munkar dalam QS 3:110 dan 3:114; (7) Tolong menolong dalam QS 5:2, 9:11 dan 107:1-3;

\footnotetext{
${ }^{39}$ Hasbi Ash-Shiddiqie, Fakta Keagungan Syarî‘at Islam (Jakarta: Bulan Bintang. 1982), hlm. 25-26.

${ }^{40}$ A. Djazuli, Ushûl Fiqh. hlm. 21.
} 
serta (8) Toleransi dalam QS 2:256, 6:108, 10:99 dan 60:8. ${ }^{41}$

Dari uraian tersebut, tampaknya prinsipprinsip dan asas-asas hukum Islam dapat ditransformasikan dari fiqh menjadi sebuah undang-undang (al-tarîkh al-syarî'ah fi al-taqnîn). Namun dalam kaitan ini, diperlukan suatu bentuk partisipasi kolektif yang dimulai dari gagasan dan kesadaran hukum Islam seorang muslim sampai kepada tingkat unifikasi dan kodifikasi hukum secara kolektif di tingkat pemerintahan dan negara.

\section{E. Teori-teori Berlakunya Hukum Islam}

Dalam perkembangannya teori-teori tersebut diperkenalkan oleh para ahli hukum berhubungan dengan kepentingan bagi keberlakuan hukum Islam di Indonesia, muali dari tingkatan metodologi hingga tingkatan realitas kehidupan masyarakat Islam itu. Berikut ini teori-teori yang membuktikan berlakunya hukum Islam di Indonesia:

\section{Ajaran Islam sebagai Penataan Hukum}

Al-Quran memberikan ketentuan kepada setiap orang Islam untuk mentaati Allah dan Rasul-Nya, dan tidak dibenarkan seorang Islam memakai hukum selain yang datang dari Allah dalam nash, walaupun dalam aplikasinya disesuaikan dengan peru-bahan sosial dan hukum di masyarakat. Aya-ayat AlQuran yang dianggap memiliki landasan yuridis untuk berlakunya hukum Islam, antara lain: ${ }^{42}$

a. Menggambarkan permohonan orang Islam untuk berjalan di jalan yang lurus dan tidak dijauhkan dari aturan yang hak (QS 1:5);

b. Menentukan bahwa orang Islam diperintahkan untuk taat dan patuh kepada Allah dan Rasul-nya serta ulul amri (QS 4:59);

${ }^{41}$ Soenarjo, dkk. al-Qur'an dan Terjemahnya (Jakarta: Depag RI, 1987). Sumber juga diambil dari materi perkuliahan Filsafat Hukum Islam pada Program Pascasarjana IAIN Sunan Gunung Djati Bandung, di mana Juhaya S. Praja menjelaskannya secara terperinsi dan sistematis tentang "Hierarki Hukum Islam." (diambil dari Hasil Materi Kuliah Filsafat Hukum Islam semester II-III tahun 1999 di PPS IAIN SGD Bandung).

${ }^{42}$ Ichtiyanto, Pengembangan Teori Berlakunya Hukum Islam di Indonesia (Bandung: Rosda Karya. ${ }_{1991}$ ), hlm. 100-103. c. Menjelaskan bahwa setiap orang Islam diharuskan tunduk kepada segala peraturan Allah dan Rasul-Nya serta berpegang teguh kepada Al-Quran dan Sunnah (Qs 24:52).

Dari pokok-pokok pikiran tersebut, tampak bahwa segi penaatan kepada hukum Islam bukan semata-mata prinsip hukum yang memuat ajaran-ajaran moral dan etika, melainkan universalitas hukum Islam mencakup semua peraturan yang berfungsi menjadi pedoman/penuntun kehidupan manusia. Karena itu, dimensi vertikal dan horizontal hukum Islam sesungguhnya merupakan hukum tertinggi yang tidak dimiliki berbagai sistem hukum lainnya.

\section{Teori Penerimaan Otoritas Hukum}

Teori ini dikemukakan oleh H.A.R. Gibb dalam The Modern Trends of Islam yang menyatakan bahwa setiap orang Islam diharuskan tunduk dan patuh kepada otoritas hukum agama yang dianutnya. ${ }^{43}$ Dengan kata lain, bagi orang Islam terdapat kewajiban untuk menjalankan syarî́at Islam dalam bentuk ketaatan yang universal dan paripurna.

Berdasarkan kepada pandangan Gibb tersebut, berarti Islam dapat dipahami sebagai alat yang ampuh untuk mempersatukan etika sosial masyarakat Islam. Walaupun dalam perkembangan masyarakat dikenal keragaman pemahaman tentang hukum Islam, dan sekaligus akan berimplikasi kepada upaya mempertahankan eksistensi hukum Islam yang senantiasa relevan dengan situasi dan kondisi zaman yang terus berubah.

\section{Teori Receptie in Complexue}

Teori receptie in complexue diperkenalkan oleh Prof. Mr. Lodewijk Willem Christian van den Berg (1845-1927 M), yang menyatakan bahwa bagi orang Islam berlaku penuh hukum Islam, sebab ia telah memeluk agama Islam walaupun dalam pelak-sanaannya terdapat penyimpangan-penyimpangan. ${ }^{44}$ Menurut van den Berg, hukum Islam telah berlaku pada masyarakat asli Indonesia sejak

\footnotetext{
${ }^{43}$ H.A.R. Gibb, The Modern Trends of Islam. hlm. 114.

${ }^{44}$ Ibid. hlm. 117.
} 
$1885 \mathrm{M}$ yang diperkuat dengan adanya Regeering Reglement, dan hukum perkawinan dan kewarisan Islam dalam suatu compendium Freijer tahun $1706 .{ }^{45}$

Di samping itu, van den Berg berasumsi bahwa peraturan tentang Mahkamah Syar'iyah dalam stbl.1882 No.152 jo. merupakan hukum yang berlaku bagi rakyat pribumi yang notabene mayoritas Islam. Misalnya Pengadilan Serambi yang dilaksanakan di serambi mesjid, banyak diberlakukan kerajaankerajaan Islam di Kalimantan, Sulawesi Selatan, Maluku dan Irian yang disebut dengan Majelis Syuro atau Hakim Syara'. Sedangkan di Sumatera dikenal dengan Mahkamah Syar'iyah. ${ }^{46}$

Van den Berg ingin berperan dalam memberikan pemahaman tentang hukum Islam kepada para pejabat Belanda saat itu. Tulisannya tentang hukum waris Islam di Jawa dan Madura (1892 M) dan hukum Islam (Mohammadaasch Recht menurut Syâfi i dan Hânafi) tahun $1882 \mathrm{M}$ telah membuktikan penyimpangan hakim-hakim agama Islam terhadap pasal 75 dan 78 yang melaksanakan hukum-hukum agama menurut kebiasaan (Reglement of Het Beleid der Regeering ven Netherlandsch Indie (RR) Stbl. 1885 No.2) ${ }^{47}$

\section{Teori Receptie}

Teori Receptie diperkenalkan oleh Prof. Christian Snouck Hugronye (1857-1936 M) yang kemudian dikembangkan oleh $C$. van Vollen Hoeven dan Ter Haar. Snouck Hugronye sendiri dikenal sebagai penasehat pemerintah Hindia Belanda tentang soal-soal Islam dan anak negeri tahun 1898. la pernah pergi ke Mekkah dan belajar tentang Islam hingga berganti nama menjadi Abdul Gaffar. Keahliannya dalam mempelajari hukum Islam dan hukum adat diwujudkan dalam karyanya De Atjehhers dan De Gojoand. ${ }^{48}$

Dalam pokok-pokok teori receptie, Hugronye menyebutkan bahwa bagi rakyat pribumi pada dasarnya berlaku hukum adat,

${ }^{45}$ A. Hânafi, Teologi Islam (Jakarta: Pustaka AlHusna, 1987), hlm. 138. Taufiq Idris, Aliran-aliran Populer dalam Teologi Islam (Surabaya: Bina IImu. 1980), hlm. 18.

${ }^{46}$ Juhaya S. Praja, Hukum Islam di Indonesia (Bandung: Rosda Karya. 1993), hlm. 118-120.

${ }^{47}$ Ichtiyanto, Pengembangan Teori. hlm. 118-120.

${ }^{48}$ Ibid. hlm. 120-122. dan hukum Islam akan berlaku apabila borma hukum Islam telah diterima/diserap oleh masyarakat hukum adat. Teori ini dikembangkan oleh Vollen Hoeven dan Ter Haar semata-mata untuk kepentingan munculnya panIslamisme di Indonesia serta untuk memperkokoh cengkraman penjajahan di Indonesia.

Hal ini dibuktikan dengan ditetapkannya stbl.1882 No.152 jo yang mencakup atas tiga point: Pertama, Bagi orang Islam diberikan kebebasan tanpa syarat untuk melaksanakan ajarannya; Kedua, Pemerintah Belanda menghormati adat istiadat dan kebiasaan masyarakat pribumi; Ketiga, Dalam sistem ketatanegaraan dicegah upaya-upaya hukum untuk menekan gerakan pan-Islamisme. ${ }^{49}$

Dari ketiga rumusan teori dalam stbl.1882 No.152 jo tersebut, ketika teori receptie ini diterima oleh kurang lebih 19 wilayah hukum masyarakat adat, dan dipertegas oleh pasal 137 IS tentang Hukum Islam telah meresap dalam hukum adat, selanjutnya pemerintah Belanda menetapkan kebijakan politik hukum untuk menghapuskan hukum Islam dengan cara:

a. Hukum Hudud dan Qishash dihapuskan dan diganti dengan Wetboek van Straftrecht Nederland tahun 1919 M melalui stbl.1925 No.732.

b. Hukum Tata Negara yang berlaku dihapuskan dan lepas dari nilai-nilai dalam AlQuran dan Sunnah diganti oleh prinsip demokrasi sekuler Barat.

c. Mempersempit ruang gerak hukum mu'amalah dengan cara: (1) menghapus wewenang Peradilan Agama di Jawa dan Kalimantan mengenai waris; (2) Pemberian wewenang penyelesaian waris dengan hukum Perdata Barat atau Landraad; (3) Larangan memberlakukan hukum Islam pada masyarakat hukum adat. $^{50}$

Kemudian tahun 1937 M Ter Haar mengeluarkan kebijakan politik hukum untuk mengurangi wewenang Pengadilan Agama

\footnotetext{
${ }^{49}$ Abu Bakar Aceh, Islam: Sumber Jihad dan ljtihad (Jakarta: UID Press. 1987), hlm. 23.

${ }^{50}$ Dipetik dari tulisan tentang Hukum Pidana Islam ditinjau dari Segi Dasar-dasar dan Asas Tata Hukum Nasional (Jakarta: Majelis Ilmiah Islamiyah. Januari 1963).
} 
melalui stbl.1937 No.116,610, 638 dan 639 tentang masalah waris untuk:

a. Stbl 1937 nomor 116 tentang Pengadilan Agama untuk Jawa dan Madura (Pengadilan Tingkat Pertama);

b. Stbl 1937 nomor 610 tentang Mahkamah Tinggi syar'iyah (Pengadilan Tingkat Banding);

c. Stbl 1937 nomor 638 tentang Kerapatan Qadhi di Kalimantan Selatan;

d. Stbl 1937 nomor 639 tentang Kerapatan Qadhi Besar tingkat banding di Kalimantan Selatan.

Penentangan terhadap teori receptie terus berlangsung hingga masa awal persiapan Kemerdekaan Indonesia antara duet H.O.S. Cokroaminoto dan H. Agus Salim melawan Mr. Soepomom dalam Sidang BPUPKI tanggal 18 Agustus 1945. Pada saat perumusan konstitusi negara Pancasila dan UUD 1945 yang akhirnya diterima oleh kalangan Islam karena dianggap memuat semangat Piagam Jakarta. ${ }^{51}$

\section{Teori Receptie Exit}

Teori receptie exit dikemukakan oleh Hazairin yang memberikan pertentangan terhadap teori receptienya Snouck Hugronye. Menurut Hazairin, hukum Islam adalah hukum yang mandiri dan lepas dari pengaruh hukum lainnya, sebagaimana ia menghubungkannya dengan sumber dan metode hukum Islam..$^{52}$ Dan ketika Indonesia memasuki masa kemerdekaannya, hukum Islam mewarnai sistem hukum nasional dan tatanan kehidupan masyarakat Islam di Indonesia.

Alasan yang dikemukakan oleh Hazairin didasarkan pada pembukaan UUD 1945 bahwa "Atas berkat rahmat Allah Yang Maha Kuasa dan didorong oleh keinginan yang luhur dan bebas, maka dengan ini bangsa Indonesia menyatakan kemerdeka-annya." Dipertegas lagi dalam alinea IV Pembukaan UUD 1945: "Negara berdasarkan Ketuhanan

\footnotetext{
${ }^{51}$ Ichtiyanto, Pengembangan Teori. hlm. 125-127.

${ }^{52}$ Penentangan Hazairin terhadap teori Receptienya Snouck Hugronye disebut dengan "Teori Iblis" karena asumsi-asumsi Snouck Hugronye sama sekali tidak memiliki dasar hukum atau logika yang murni.
}

Yang Maha Esa." Merupakan kompromi untuk memberlakukan syarî́at Islam dalam konstitusi negara. ${ }^{53}$

Selain itu, Batang Tubuh UUD 1945 pasal 29 ayat (1-2) merupakan jaminan bagi berlangsungnya penerapan hukum Islam di Indonesia, dan dengan sendirinya teori receptie Snouck Hugronye tertolak. Dalam perkembangan kemudian adanya Departemen Agama yang berdiri pada tangga 3 Januari 1946 M merupakan beserta pranata-pranata sosial, budaya, politik, dan hukum bercorak Islam adalah implementasi penerapan syari'ah Islam di Indonesia.

\section{Teori Receptie a Contrario}

Teori receptie a contrario merupakan pengembangan dari teori receptie exit Hazairin. Sayuti Thalib dalam tulisannya Receptie a Contrario: Hubungan Hukum Adat dengan Hukum Islam, penelitiannya tentang masalah perkawinan dan waris disimpulkan bahwa:

a. bagi orang Islam berlaku hukum Islam.

b. Hukum Islam berlaku sesuai dengan cita hukum, cita moral dan bathin umat Islam.

c. Hukum adat berlaku, jika tidak bertentangan dengan ajaran Islam.

Berdasar ketiga uraian tersebut, Sayuti Thalib dan Hazairin berpendapat bahwa teori receptie Hugronye sebagai teori iblis, karenanya bukan berasal dari kemauan hukum syarîat serta akal sehat. Pada gilirannya dapat dipahami, bahwa hukum Islam tetap berdiri sendiri dan tidak ditundukkan oleh hukum adat, tetapi Islamlah sesungguhnya yang telah mewarnai hukum adat itu.

Kendatipun rumusan-rumusan teori hukum tersebut menunjukkan berlakunya hukum Islam di Indonesia, tetapi fakta sejarah perkembangan hukum Islam dapat dijadikan bukti kuat dan sekaligus mempertegas eksistensinya yang berbaur denga kultur dan budaya masyarakat Islam, serta sistem ketatanegaraan Indonesia. Tinggal bagaimana rumusan-rumusan teori hukum itu dapat di-

\footnotetext{
${ }^{53}$ Muhammad Daud Ali, Hukum Islam: Pengadilan Agama dan Masalahnya (Bandung: Rosdakarya. 1991), hlm. 74 .
} 
kembangkan lagi sampai kepada tingkat transformasi hukum ke dalam undang-undang.

\section{F. Penutup}

Mengacu kepada pemaparan di atas, pada bagian akhir tulisan ini penulis ingin menegaskan bahwa corak pemikiran hukum Islam memberi dampak signifikan bagi keberlakuan hukum Islam itu sendiri. Gambaran sejarah berlakunya hukum Islam di Indonesia berikut produk-produk hukum Islam merupakan sebagian dari perjalanan sejarah hukum Islam. Pada gilirannya, hasil dari pemikiran-pemikiran hukum Islam yang menjelaskan teori-teori hukum Islam, telah menjadi kekayaan dan khazanah pemikiran Islam mulai dari periode klasik hingga modern.

\section{Daftar Pustaka}

Aceh, Abu Bakar. 1987. Islam: Sumber Jihad dan ijtihâd. Jakarta: UID Press.

Anonimous. 1963. Hukum Pidana Islam ditinjau dari Segi Dasar-dasar dan Asas Tata Hukum Nasional. Jakarta: Majelis Ilmiah Islamiyah.

Ash-Shiddiqie, Hasbie. 1975. Dinamika dan Elastisitas Hukum Islam. Jakarta: Tintamas.

. 1975. Pengantar Hukum Islam. Jakarta: Bulan Bintang.

- 1982. Fakta Keagungan Syarî́at

Islam. Jakarta: Bulan Bintang.

. 1993. Falsafah Hukum Islam. Jakarta: Bulan Bintang.

Djamil, Fathurrahman. 1997. Filsafat Hukum Islam. Jakarta: Logos Wacana Ilmu.

Fyzee, A. A. 1995. Out Lines of Muhammad Law. London: Oxford University Press.

Hânafi, A. 1970. Pengantar dan Sejarah Hukum Islam. Jakarta: Bulan Buntang. . 1987. Teologi Islam. Jakarta: Pustaka Al-Husna.

Haryono, Anwar. 1985. Hukum Islam: Keluasan dan Keadilannya. Jakarta: Bulan Bintang.

Ichtiyanto. 1991. Pengembangan Teori Berlakunya Hukum Islam di Indonesia. Bandung: Rosda Karya.
Idris, Taufiq. 1980. Aliran-aliran Populer dalam Teologi Islam. Surabaya: Bina Ilmu.

Jawziyah, Ibn Qayyim, al-. t.th. 'I'lâm al-Muwaqqin 'an Rabi al-'Âlamîn. Beirut: Dâr alFikr.

Khallâf, Abdul Wahhâb. 1969. Ilmu Ushûl alFiqh. Kairo: Dâr al-Fikr, Maktabah Tijâriyah al-Kubrâ.

. 1977. Al-Siyâsah al-Syar'iyyah. Kairo: Dâr al-Anshâr.

Muhammad Daud, Ali. 1991. Hukum Islam: Pengadilan Agama dan Masalahnya. Bandung: Rosdakarya.

Musa, Yusuf. t.th. Târîkh al-Fiqh al-Islâmiy. Kairo: Mesir.

Muslehudin, Muhammad. 1992. Filsafat Hukum Islam dan Pemikiran Orientalis, terj. Yudian Wahyudi. Yogyakarta: Tiara Wacana.

Muthahari, Murtadha dkk. 1993. Pengantar Ushûl Fiqh dan Ushûl Figh Perbandingan, terj. Satrio Pinandih dan Ahsin Muhammad. Jakarta: Pustaka Hidayah.

Praja, Juhaya S. 1993. Hukum Islam di Indonesia. Bandung: Rosda Karya.

Qaththân, Manna', al-. t.th. al-Târîkh wa Fiqh fî al-Islâm. t.t.: Mu'assasah al-Risâlah.

Rosyada, Dede. 1994. Hukum Islam dan Pranata Sosial. Jakarta: Rajawali Press.

Schacht, Joseph. 1985. Introduction of Islamic Law. terj. M. Said dkk. Jakarta: PPS \& PTAI \&\& Ditjen Binbaga Islam Depag RI.

Soenarjo dkk. 1987. Al-Quran dan Terjemahnya. Jakarta: Depag RI.

Sulayman, Abû dkk. 1983. Fikr al-Ushûliy. Jeddah: Dâr al-Syurûq.

Syafe'i, Rachmat. 1994. Pengantar Ushûl Fiqh Perbandingan. Bandung: Piara.

Syarifudin, Amir. 1992. Pengertian dan Sumber Hukum Islam dalam Falsafah Hukum Islam. Jakarta: Bumi Aksara.

Syâthibi, Abu Ishaq, al-. t.th. al-Muwâfaqât fî Ushûl al-Ahkâm. Beirut: Dâr al-Fikr.

Yusuf, M. Yunan et. Al. 1985. Cita dan Citra Muhammadiyah. Jakarta: Pustaka Panjimas.

Zahrah, Abû dkk. 1973. Ushûl al-Fiqh. Mesir: Dâr al-Fikr al-‘Arabi. 